\title{
Yield and Postharvest Quality of Lettuce in Response to Nitrogen, Phosphorus, and Potassium Fertilizers
}

\author{
M. Murshidul Hoque, Husein Ajwa ${ }^{1}$, and Mona Othman \\ Department of Plant Sciences, University of California, Davis, 1636 E. Alisal \\ Street, Salinas, CA 93905

\section{Richard Smith and Michael Cahn \\ University of California Cooperative Extension, Monterey County, 1432 Abbott Street, Salinas, CA 93901}

Additional index words. Lactuca sativa, postharvest quality, nitrogen, phosphorus, potassium, romaine lettuce, iceberg lettuce

\begin{abstract}
Commercial lettuce production requires adequate levels of nitrogen $(\mathrm{N})$ phosphorus (P), and potassium (K) to provide high-quality postharvest attributes needed for longer shelf life. Factorial experiments were conducted in Salinas, CA, to evaluate yield and postharvest quality of both romaine and iceberg lettuce using fertilizers containing various levels of $\mathbf{N}, \mathbf{P}$, and $\mathrm{K}$. Lettuce was evaluated for yield and postharvest quality parameters, including color, wilt, turgidity, glossiness, decay, brittleness, fringe burn, and salt burn. Uptake of N, P, K, calcium, and silicon by plants was also determined. Regardless of fertilizer treatment, shelf life and visual quality were better in the iceberg lettuce than romaine lettuce when cold-stored at $1{ }^{\circ} \mathrm{C}$ for $14 \mathrm{~d}$. Yield increased with increased $\mathrm{N}$ application rate, but post-harvest quality fell at high levels of $N\left(337 \mathrm{~kg} \cdot \mathrm{ha}^{-1}\right)$ and $P(225$ $\left.\mathrm{kg} \cdot \mathrm{ha}^{-1}\right)$. The most economical treatment providing the highest yield and best post-harvest quality was the combination of $225 \mathrm{~kg} \cdot \mathrm{ha}^{-1} \mathrm{~N}$ and $112 \mathrm{~kg} \cdot \mathrm{ha}^{-1} \mathrm{P}$.
\end{abstract}

Chemical fertilizers have made substantial contributions to increased crop yields and food nutrition (Fageria, 2009; Wang et al., 2008). However, excessive fertilizer application can have adverse environmental effects on water quality, leaching, and runoff (Heckman, 2007; Heckman et al., 2003; Manotti et al., 1994; Sims, 1998; Sims et al., 1998). Therefore, it is important to determine fertilizer application rates that maximize yields while minimizing environmental pollution (Fontes et al., 1997; Heckman et al., 2003).

The Salinas Valley, located in the Central Coast region of California, has a severe problem with nitrate- $\mathrm{N}\left(\mathrm{NO}_{3}-\mathrm{N}\right)$ contamination of groundwater related to intensive vegetable production typically using more than $150 \mathrm{~kg}$ nitrogen (N)/ha/crop (Jackson et al., 1994). Similarly, the excessive accumulation of soil phosphorus (P) has raised water quality concerns (Sims, 1998). Salinas Valley soils often contain more than 30 to $40 \mathrm{mg} \cdot \mathrm{kg}^{-1}$ of bicarbonate extractable $\mathrm{P}$ (Olsen test), which is the recommended soil $\mathrm{P}$ level for cool-season vegetables (Smith et al., 2006).

Optimal fertilizer management and efficient use of N, P, and potassium $(\mathrm{K})$ are necessary to improve yield and quality and to reduce production cost (Fageria, 2009). Although some studies indicate that adequate lettuce yield can be achieved with low $\mathrm{N}$ application rates

Received for publication 24 May 2010. Accepted for publication 16 Aug. 2010.

${ }^{1}$ To whom reprint requests should be addressed; e-mail haajwa@ucdavis.edu.
(Soundy and Smith, 1992), others suggest that high rates of $\mathrm{N}$ might be required to achieve maximum yields (Carling et al., 1987). Although high nitrate uptake generates higher nitrite accumulation and improved leaf morphology (e.g., leaf length and width), leaf thickness can be significantly reduced (Tittonell et al., 2001). Therefore, nitrate content in leaf tissues at harvest affects lettuce quality. High $\mathrm{N}$ in lettuce generally leads to storage disorders and the potential for rapid postharvest decay (David et al., 1992).

Postharvest decay in lettuce and other vegetable crops is a major source of financial loss for producers. Consumers evaluate lettuce based on its taste, texture, and appearance (Morris et al., 1974). Although studies indicate that $\mathrm{N}$ availability in the soil can affect lettuce quality (Tittonell et al., 2001), there is no information about the effect of various levels of N, P, and K on the postharvest quality of lettuce. With desirable quality at harvest, careful handling, and continuous control of the postharvest environment, lettuce can be successfully marketed to the consumer as long as 2 to 3 weeks postharvest (Morris, 1974).

Lettuce shows a pronounced yield and quality response to $\mathrm{P}$ fertilizer under most conditions (Alt, 1987; Johnstone et al., 2005; Sanchez and Burdine, 1988; Sanchez et al., 1988). Soundy and Smith (1992) report a significant positive linear correlation between soil $\mathrm{P}$ and head tissue P. Lettuce was reported to have higher $\mathrm{P}$ fertilizer requirements than most other vegetables across a range of soils (Cleaver and Greenwood, 1975). A suboptimal supply of $\mathrm{N}$ and $\mathrm{P}$ causes slower leaf growth and a lower leaf area index by limiting photosynthesis and cell expansion (Marschner, 1995). Scarce information is available regarding lettuce cultivar response to $\mathrm{P}$ fertilizer. Because lettuce produced on organic soils requires a relatively large amount of plant-available $\mathrm{P}$ for optimal yield and quality (Sanchez and Burdine, 1988), it is imperative that $\mathrm{P}$ fertilizer management strategies be evaluated. In addition, factors other than soil type and residual $\mathrm{P}$ status of soil such as planting season, variety, and fertilizer placement may change the $\mathrm{P}$ fertilizer requirement.

Studies report varied reactions of vegetable crops to K application (Alt, 1987). Soundy and Smith (1992) reported a quadratic lettuce yield model with soil $\mathrm{K}$ but that applied $\mathrm{N}$ and $\mathrm{P}$ did not affect $\mathrm{K}$ availability. Other studies suggest there may be some yield and quality benefit to $\mathrm{N}$ and $\mathrm{P}$ fertilizer application because of their role in modulating disease resistance and because of the metabolic functions of K (Marschner, 1995).

Silicon $(\mathrm{Si})$ and calcium $(\mathrm{Ca})$ play a role in lettuce yield and quality. Some studies have found a weak correlation between lettuce yield and soil $\mathrm{Ca}$ (Soundy and Smith, 1992). Although not required for plant metabolism, Si was found to relieve phosphate deficiency and improve resistance to pathogens (Bidwell, 1974). Improved resistance to fungal diseases was linked to increased $\mathrm{Si}$ content in leaves.

Limited studies are available on the effect of nutrients on lettuce postharvest quality. This study was conducted to determine the best possible combination of $\mathrm{N}, \mathrm{P}$, and $\mathrm{K}$ fertilizers for optimum yield and postharvest quality of lettuce and to identify the physiological attributes that affect the storage life of lettuce.

\section{Materials and Methods}

Field sites and fertility treatments. Field experiments were conducted at the U.S. Department of Agriculture-Agricultural Research Service research facilities in Salinas, CA, in 2002 (June through September) and in 2003 (April through August). The fine loamy sand had $75.5 \%$ sand, $19.1 \%$ silt, $5.5 \%$ clay, a $\mathrm{pH}$ of 6.5 , and $1.1 \%$ organic matter content. The soil was disked, chiseled to a depth of 20 to $30 \mathrm{~cm}$, and tilled into raised beds. After pre-plant fertilizer application of $\mathrm{N}$ and $\mathrm{P}$ only, the soil in the beds was rototilled and pressed into firm flat beds. Potassium sulfate was applied while forming the beds and incorporated by rotovation to a depth of $15 \mathrm{~cm}$ during seed bed preparation. Triple superphosphate was banded into two lines per beds at pre-plant to a depth of $10 \mathrm{~cm}$. $\mathrm{N}$ fertilizer was applied as pre-plant and as two sidedressed applications, one at $30 \mathrm{~d}$ after sowing and the other at $45 \mathrm{~d}$ after sowing. $\mathrm{N}$ fertilizers were applied $5 \mathrm{~cm}$ to the side and $5 \mathrm{~cm}$ below the seed row.

Experimental design. The experiment was conducted as a split plot design with the lettuce cultivars in the main plot and fertilizer treatments in the subplots. Fertilizer treatments 
were arranged in a $4 \times 3 \times 2$ factorial design with four levels of $\mathrm{N}$, three levels of $\mathrm{P}$, and two levels of $\mathrm{K}$ fertilizer treatment combinations. Each treatment was replicated four times. Two types of lettuce, Lactuca sativa L., romaine var. 'Green Tower' and head lettuce var 'Sharp Shooter' (Harris Moran Seed Company, Modesto, CA), were used. Each treatment was assigned to three plots of $24 \mathrm{~m} \times 1-\mathrm{m}$ beds. $\mathrm{N}$ treatments were $0,112,225$, and $337 \mathrm{~kg} \cdot \mathrm{ha}^{-1} ; \mathrm{P}$ treatments were $0,112,168$, and $225 \mathrm{~kg} \cdot \mathrm{ha}^{-1}$; and $\mathrm{K}$ treatments were: 0 and $112 \mathrm{~kg} \cdot \mathrm{ha}^{-1}$. Lettuce seeds were mechanically seeded into two rows on the bed with $40 \mathrm{~cm}$ between rows, and plants were thinned to a final spacing of $25 \mathrm{~cm}$ for romaine and $30 \mathrm{~cm}$ for head lettuce giving a plant density of 120 and 150 per plot, respectively. $\mathrm{N}$ applications were basal, side-dress one, and side-dress two as follows: 22,45 , and $45 \mathrm{~kg} \cdot \mathrm{ha}^{-1}$ for the 112 $\mathrm{kg} \cdot \mathrm{ha}^{-1}$ rate; 22,45 , and $157 \mathrm{~kg} \cdot \mathrm{ha}^{-1}$ for the $225-$ $\mathrm{kg} \cdot \mathrm{ha}^{-1}$ rate; and 22,157 , and $157 \mathrm{~kg} \cdot \mathrm{ha}^{-1}$ for the $337-\mathrm{kg} \cdot \mathrm{ha}^{-1}$ rate.

Lettuce was irrigated with a solid-set sprinkler irrigation system based on estimated potential evapotranspiration reported by the California Irrigation Management Information System weather station. Irrigation water was applied at 2- to 3 -d intervals for 3 to $4 \mathrm{~h} \cdot \mathrm{d}^{-1}$ and irrigation was discontinued a few days before harvest. The standard pre-emergence herbicide (Kerb 50W at $3.4 \mathrm{~kg} \cdot \mathrm{ha}^{-1}$; Dow AgroSciences LLC, Indianapolis, IN) was applied to suppress the weeds. Weeding and pesticide applications followed commercial production practices.

Soil sampling and analysis. Pre-fertilization soil samples (five cores from each subplot) ( 0 to $15 \mathrm{~cm}$ depth) were taken with a soil probe. Soil was dried, sieved (2-mm mesh), and analyzed for total Kjeldahl nitrogen, $\mathrm{NO}_{3}-\mathrm{N}$, Olsen-P, and extractable K. Soil samples were collected before each side-dressed application of $\mathrm{N}$ fertilizer and immediately after the final harvest of both cultivars. Soil fertility analyses were conducted by the University of CaliforniaDavis, Department of Agriculture and Natural Resources (DANR), as described on the DANR web site: http://danranlab.ucanr.org.

Agronomic and yield parameters. Romaine lettuce was harvested $78 \mathrm{~d}$ after planting and iceberg lettuce was harvested $83 \mathrm{~d}$ after planting. A total of 30 plants was sampled from the center four seed rows by selecting every eighth marketable plant in a row. Wholeplant weight from a composite sample of 10 plants was determined. Leaves from the whole plant were stripped to obtain a marketable size and the plant was reweighed. Subsamples were retained for tissue analysis. Tissue samples were dried at $60{ }^{\circ} \mathrm{C}$ for $48 \mathrm{~h}$ and reweighed to determine moisture content. Oven-dried samples were ground to pass through a 40-mesh screen and analyzed for $\mathrm{NH}_{4}-\mathrm{N}, \mathrm{NO}_{3}-\mathrm{N}$, and total $\mathrm{N}, \mathrm{P}, \mathrm{K}, \mathrm{Ca}$, and $\mathrm{Si}$ according to procedures described on the DANR web site (http://danranlab.ucanr.org).

For marketable yield, commercial lettuce harvest crews harvested plants from the center four rows of plots in all treatments. Except the control $\mathrm{N}$ treatments, heads were packed into three boxes. Iceberg lettuce was packed in a plastic sheet and stored in a commercial box for cooling. Romaine was packed in waxed boxes. Commercial sizes of $24 \mathrm{~s}$ or $30 \mathrm{~s}$ (accommodated no. in box) were packed depending on availability. Each packed box was weighed on a field scale. The boxes were placed on pallets. Iceberg lettuce was vacuum-cooled and romaine was hydrocooled before storing in the cooler at 1 to $2{ }^{\circ} \mathrm{C}$. Lettuce was stored according to color in a commercial cooling facility (American Cooler, Salinas, CA) for evaluation of postharvest quality.

Postharvest quality evaluations. For the postharvest quality evaluations, the following postharvest parameters were evaluated for romaine lettuce: wilting, decay, brittleness, glossiness, and salt burn. For iceberg, the following parameters were evaluated: defects, fringe burn, turgidity, firmness, and color. Five heads from each box in the cooler were randomly chosen for visual evaluation. Each of the parameters were assigned a value of 0 to 4 in which $0=$ excellent, $1=$ very good, $2=$ average, $3=$ poor, and $4=$ unacceptable (Kader et al., 1973). A combined rating index was calculated by summing the differences between 7 and $21 \mathrm{~d}$ for all rating scores of the postharvest parameter. Sugar content of lettuce was determined by spectrophotometer as described by Buysse and Merckx (1993).

Statistical analysis. As a result of differences in the initial soil P levels between the years, data for the two seasons were analyzed separately. Each year's results were analyzed using a factorial analysis of variance (ANOVA, PROC MIXED) and Duncan's least significant difference to examine differences among the treatment levels for each lettuce type. The Statistical Analysis System (SAS Institute, 1996) was used for the analyses. SAS was also used for non-linear regression analyses of the effect of fertilizer levels on lettuce yields (quadratic equation).

\section{Results and Discussion}

Soil and lettuce tissue analysis. Soil N, P, and $\mathrm{K}$ concentrations at final harvest are shown in Tables 1 and 2 for romaine and iceberg lettuce, respectively. Although a large amount of N ( 225 and $337 \mathrm{~kg} \cdot \mathrm{ha}^{-1}$ ) was applied to some treatments during the growing season, the residual $\mathrm{N}$ concentrations in the root zone were small at harvest as a result of plant uptake,

Table 1. Soil sample analysis at the final harvest of romaine lettuce.

\begin{tabular}{lcccr}
\hline Treatment & $\begin{array}{c}\mathrm{TKN} \\
\left(\mathrm{mg} \cdot \mathrm{kg}^{-1}\right)\end{array}$ & $\begin{array}{c}\mathrm{NO}_{3}-\mathrm{N} \\
\left(\mathrm{mg} \cdot \mathrm{kg}^{-1}\right)\end{array}$ & $\begin{array}{c}\text { Phosphorus } \\
\left(\mathrm{mg} \cdot \mathrm{kg}^{-1}\right)\end{array}$ & $\begin{array}{r}\text { Potassium } \\
\left(\mathrm{mg}^{\mathrm{z}} \cdot \mathrm{kg}^{-1}\right)\end{array}$ \\
\hline $\mathrm{N}_{0} \mathrm{P}_{0} \mathrm{~K}_{0}$ & 578 & 1.13 & 30.3 & 110.0 \\
$\mathrm{~N}_{0} \mathrm{P}_{0} \mathrm{~K}_{112}$ & 520 & 0.55 & 26.0 & 139.3 \\
$\mathrm{~N}_{0} \mathrm{P}_{112} \mathrm{~K}_{112}$ & 575 & 1.63 & 37.6 & 144.5 \\
$\mathrm{~N}_{0} \mathrm{P}_{225} \mathrm{~K}_{112}$ & 537 & 0.70 & 35.2 & 148.8 \\
$\mathrm{~N}_{112} \mathrm{P}_{112} \mathrm{~K}_{0}$ & 567 & 1.33 & 23.3 & 115.5 \\
$\mathrm{~N}_{112} \mathrm{P}_{0} \mathrm{~K}_{112}$ & 540 & 1.45 & 39.6 & 94.5 \\
$\mathrm{~N}_{112} \mathrm{P}_{112} \mathrm{~K}_{112}$ & 602 & 0.75 & 43.3 & 142.3 \\
$\mathrm{~N}_{112} \mathrm{P}_{225} \mathrm{~K}_{112}$ & 573 & 1.25 & 40.0 & 110.8 \\
$\mathrm{~N}_{225} \mathrm{P}_{112} \mathrm{~K}_{0}$ & 580 & 4.35 & 21.4 & 141.0 \\
$\mathrm{~N}_{225} \mathrm{P}_{0} \mathrm{~K}_{112}$ & 605 & 2.05 & 39.5 & 100.8 \\
$\mathrm{~N}_{225} \mathrm{P}_{112} \mathrm{~K}_{112}$ & 590 & 4.30 & 30.4 & 121.5 \\
$\mathrm{~N}_{225} \mathrm{P}_{225} \mathrm{~K}_{112}$ & 560 & 10.20 & 41.8 & 101.8 \\
$\mathrm{~N}_{337} \mathrm{P}_{112} \mathrm{~K}_{0}$ & 627 & 16.30 & 22.6 & 116.5 \\
$\mathrm{~N}_{337} \mathrm{P}_{0} \mathrm{~K}_{112}$ & 600 & 8.98 & 38.1 & 101.3 \\
$\mathrm{~N}_{337} \mathrm{P}_{112} \mathrm{~K}_{112}$ & 565 & 5.63 & 25.8 & 122.8 \\
$\mathrm{~N}_{337} \mathrm{P}_{225} \mathrm{~K}_{112}$ & 577 & 3.45 & 45.5 & 142.5 \\
LSD $_{(0.05)}$ & 65 & 11.60 & 21.5 & 35.9 \\
\hline
\end{tabular}

${ }^{\mathrm{z}}$ Subscripts correspond to fertilizer application rates $\left(\mathrm{kg} \cdot \mathrm{ha}^{-1}\right)$.

$\mathrm{TKN}=$ total Kjeldahl nitrogen.

Table 2. Soil sample analysis at the final harvest of iceberg lettuce.

\begin{tabular}{|c|c|c|c|c|}
\hline Treatment & $\begin{array}{c}\mathrm{TKN} \\
\left(\mathrm{mg} \cdot \mathrm{kg}^{-1}\right)\end{array}$ & $\begin{array}{c}\mathrm{NO}_{3}-\mathrm{N} \\
\left(\mathrm{mg} \cdot \mathrm{kg}^{-1}\right)\end{array}$ & $\begin{array}{c}\text { Phosphorus } \\
\left(\mathrm{mg} \cdot \mathrm{kg}^{-1}\right)\end{array}$ & $\begin{array}{c}\text { Potassium } \\
\left(\mathrm{mg} \cdot \mathrm{kg}^{-1}\right)\end{array}$ \\
\hline$\overline{\mathrm{N}_{0} \mathrm{P}_{0} \mathrm{~K}_{0}}$ & 573 & 0.83 & 24.1 & 105.5 \\
\hline $\mathrm{N}_{0} \mathrm{P}_{0} \mathrm{~K}_{112}$ & 595 & 0.65 & 22.4 & 98.5 \\
\hline $\mathrm{N}_{0} \mathrm{P}_{112} \mathrm{~K}_{112}$ & 573 & 0.78 & 26.9 & 113.5 \\
\hline $\mathrm{N}_{0} \mathrm{P}_{225} \mathrm{~K}_{112}$ & 545 & 0.55 & 26.2 & 116.0 \\
\hline $\mathrm{N}_{112} \mathrm{P}_{112} \mathrm{~K}_{0}$ & 575 & 11.6 & 21.0 & 96.3 \\
\hline $\mathrm{N}_{112} \mathrm{P}_{0} \mathrm{~K}_{112}$ & 613 & 2.90 & 24.2 & 100.8 \\
\hline $\mathrm{N}_{112} \mathrm{P}_{112} \mathrm{~K}_{112}$ & 575 & 2.40 & 23.7 & 100.0 \\
\hline $\mathrm{N}_{112} \mathrm{P}_{225} \mathrm{~K}_{112}$ & 590 & 3.15 & 26.6 & 99.0 \\
\hline $\mathrm{N}_{225} \mathrm{P}_{112} \mathrm{~K}_{0}$ & 567 & 4.80 & 24.0 & 117.8 \\
\hline $\mathrm{N}_{225} \mathrm{P}_{0} \mathrm{~K}_{112}$ & 610 & 8.20 & 24.8 & 109.5 \\
\hline $\mathrm{N}_{225} \mathrm{P}_{112} \mathrm{~K}_{112}$ & 578 & 2.20 & 25.2 & 109.5 \\
\hline $\mathrm{N}_{225} \mathrm{P}_{225} \mathrm{~K}_{112}$ & 565 & 1.50 & 23.0 & 91.0 \\
\hline $\mathrm{N}_{337} \mathrm{P}_{112} \mathrm{~K}_{0}$ & 708 & 40.8 & 23.9 & 94.3 \\
\hline $\mathrm{N}_{337} \mathrm{P}_{0} \mathrm{~K}_{112}$ & 670 & 47.8 & 24.3 & 108.8 \\
\hline $\mathrm{N}_{337} \mathrm{P}_{112} \mathrm{~K}_{112}$ & 588 & 11.5 & 23.5 & 113.0 \\
\hline $\mathrm{N}_{337} \mathrm{P}_{225} \mathrm{~K} 1$ & 625 & 23.3 & 24.7 & 101.5 \\
\hline $\operatorname{LSD}_{(0.05)}$ & 76 & 17.9 & 5.2 & 25.2 \\
\hline
\end{tabular}

$\mathrm{TKN}=$ total Kjeldahl nitrogen; LSD = least significant difference. 
microbial immobilization, and leaching out of the root zone. The extractable $\mathrm{P}$ concentrations (Olsen-P) were high after high $\mathrm{P}$ application; however, $\mathrm{P}$ levels in all plots at harvest were similar to pre-application concentrations, indicating that the applied excess $\mathrm{P}$ fertilizer was converted into less available, non-extractable forms.

Lettuce tissue concentrations of $\mathrm{N}, \mathrm{P}, \mathrm{K}$, $\mathrm{Ca}$, and $\mathrm{Si}$ at final harvest are shown in Tables 3 and 4 for romaine and iceberg lettuce, respectively. Higher $\mathrm{N}$ fertilizer application rates increased the tissue $\mathrm{N}$ concentrations. High $\mathrm{NO}_{3}-\mathrm{N}$ accumulation in leafy vegetables is expected because lettuce is harvested at the vegetative growth stage (Wang et al., 2008). Increasing $\mathrm{N}, \mathrm{P}$, and $\mathrm{K}$ fertilizer application rate did not have a significant effect on tissue $P$ or K (Tables 3 and 4). A study by Soundy and Smith (1992) found that application of $\mathrm{N}$ and $\mathrm{P}$ did not affect $\mathrm{K}$ availability and uptake by plants. However, the nutrient concentrations in lettuce tissues were considerably different in the $\mathrm{N}$ fertilization treatments than in plots that did not receive $\mathrm{N}$ fertilizer.

High $\mathrm{Ca}$ and $\mathrm{Si}$ in romaine tissues grown without $\mathrm{N}$ fertilizers could be the result of $\mathrm{N}$ deficiency. In addition to $\mathrm{Ca}, \mathrm{Si}$ was evaluated in our study because it is speculated that increased $\mathrm{Si}$ concentration in leaves would increase plant disease resistance and enhance yield (Marschner, 1995). In general, the effect of fertilizers on nutrient content in lettuce tissues was similar in both years.

Lettuce yield. Yields from plots that did not receive $\mathrm{N}$ fertilizer were very small and lettuce did not attain a marketable size as previously shown by Nagda and Chauhan (1991). The results of this study reflect the fact that the soil chosen for this test was low in residual N. Generally, sandy soils that have been leached by irrigation, intensively cropped, and contain low organic matter have low plant-available N (Fageria, 2009).

The application of $\mathrm{N}$ fertilizer significantly increased yield for both types of lettuce (Figs. 1 and 2). The interaction between $\mathrm{N}$ and $\mathrm{P}$ rates and yields was also significant $(P<$ $0.05)$. This study revealed that optimum yields can be achieved with $225 \mathrm{~kg} \cdot \mathrm{ha}^{-1}$ of N and 112 $\mathrm{kg} \cdot \mathrm{ha}^{-1}$ of P. Yield responses to the fertility treatments were similar in both growing seasons (2002 and 2003).

In 2002, there was a slight increase in lettuce yield with increasing $\mathrm{P}$ application rate, but this increase was not statistically significant. In 2003, there was no yield response to increased $\mathrm{P}$ fertilization rate. Yield in treatments that received $\mathrm{N}$ fertilizer was significantly $(P<0.05)$ greater than yields that did not receive $\mathrm{N}$ fertilizer regardless of the $\mathrm{P}$ or K application rates (Fig. 3). Some plants wilted in soils treated with a high $\mathrm{N}$ application rate $\left(337 \mathrm{~kg} \cdot \mathrm{ha}^{-1}\right)$, whereas others were unaffected. This was probably the result of high $\mathrm{N}$ causing luxurious leaf growth and therefore a higher demand for water (Soundy and Smith, 1992).

In our study, application of $\mathrm{K}$ (as potassium sulfate at $67 \mathrm{~kg} \cdot \mathrm{ha}^{-1}$ ) did not significantly affect the yield for either type of lettuce,
Table 3. Plant sample analysis for romaine lettuce at the final harvest.

\begin{tabular}{lccccccc}
\hline Treatment & $\begin{array}{c}\mathrm{NH}_{4}-\mathrm{N} \\
\left(\mathrm{mg} \cdot \mathrm{kg}^{-1}\right)\end{array}$ & $\begin{array}{c}\mathrm{NO}_{3}-\mathrm{N} \\
\left(\mathrm{mg} \cdot \mathrm{kg}^{-1}\right)\end{array}$ & $\begin{array}{c}\mathrm{TKN} \\
(\%)\end{array}$ & $\begin{array}{c}\text { Phosphorus } \\
(\%)\end{array}$ & $\begin{array}{c}\text { Potassium } \\
(\%)\end{array}$ & $\begin{array}{c}\text { Calcium } \\
(\%)\end{array}$ & $\begin{array}{c}\text { Silicon } \\
(\%)\end{array}$ \\
\hline $\mathrm{N}_{0} \mathrm{P}_{0} \mathrm{~K}_{0}$ & 190 & 25 & 1.80 & 0.51 & 4.06 & 0.73 & 0.28 \\
$\mathrm{~N}_{0} \mathrm{P}_{0} \mathrm{~K}_{112}$ & 183 & 18 & 1.53 & 0.47 & 3.89 & 0.62 & 0.36 \\
$\mathrm{~N}_{0} \mathrm{P}_{112} \mathrm{~K}_{112}$ & 130 & 15 & 1.77 & 0.51 & 4.17 & 0.68 & 0.32 \\
$\mathrm{~N}_{0} \mathrm{P}_{225} \mathrm{~K}_{112}$ & 198 & 18 & 2.12 & 0.50 & 3.82 & 0.60 & 0.41 \\
$\mathrm{~N}_{112} \mathrm{P}_{112} \mathrm{~K}_{0}$ & 175 & 495 & 2.83 & 0.65 & 4.66 & 0.60 & 0.15 \\
$\mathrm{~N}_{112} \mathrm{P}_{0} \mathrm{~K}_{112}$ & 243 & 378 & 2.98 & 0.72 & 4.06 & 0.56 & 0.13 \\
$\mathrm{~N}_{112} \mathrm{P}_{112} \mathrm{~K}_{112}$ & 175 & 205 & 2.52 & 0.66 & 4.41 & 0.61 & 0.14 \\
$\mathrm{~N}_{112} \mathrm{P}_{225} \mathrm{~K}_{112}$ & 375 & 800 & 2.87 & 0.61 & 3.72 & 0.45 & 0.08 \\
$\mathrm{~N}_{225} \mathrm{P}_{112} \mathrm{~K}_{0}$ & 228 & 1593 & 3.54 & 0.64 & 3.63 & 0.39 & 0.07 \\
$\mathrm{~N}_{225} \mathrm{P}_{0} \mathrm{~K}_{112}$ & 290 & 1700 & 3.66 & 0.73 & 3.28 & 0.50 & 0.07 \\
$\mathrm{~N}_{225} \mathrm{P}_{112} \mathrm{~K}_{112}$ & 165 & 1570 & 3.50 & 0.67 & 3.87 & 0.55 & 0.14 \\
$\mathrm{~N}_{225} \mathrm{P}_{225} \mathrm{~K}_{112}$ & 538 & 1580 & 3.90 & 0.74 & 3.55 & 0.48 & 0.09 \\
$\mathrm{~N}_{337} \mathrm{P}_{112} \mathrm{~K}_{0}$ & 155 & 1365 & 2.91 & 0.57 & 3.53 & 0.43 & 0.12 \\
$\mathrm{~N}_{337} \mathrm{P}_{0} \mathrm{~K}_{112}$ & 413 & 2108 & 3.96 & 0.70 & 3.19 & 0.42 & 0.06 \\
$\mathrm{~N}_{337} \mathrm{P}_{112} \mathrm{~K}_{112}$ & 295 & 1523 & 3.95 & 0.72 & 3.50 & 0.46 & 0.08 \\
$\mathrm{~N}_{337} \mathrm{P}_{225} \mathrm{~K}_{112}$ & 290 & 2168 & 3.72 & 0.68 & 3.69 & 0.51 & 0.12 \\
LSD $_{(0.05)}$ & 260 & 832 & 0.75 & 0.11 & 0.75 & 0.12 & 0.09 \\
\hline
\end{tabular}

$\mathrm{TKN}=$ total Kjeldahl nitrogen; $\mathrm{LSD}=$ least significant difference.

Table 4. Plant sample analysis for iceberg lettuce at the final harvest.

\begin{tabular}{lccccccc}
\hline Treatment & $\begin{array}{c}\mathrm{NH}_{4}-\mathrm{N} \\
\left(\mathrm{mg} \cdot \mathrm{kg}^{-1}\right)\end{array}$ & $\begin{array}{c}\mathrm{NO}_{3}-\mathrm{N} \\
\left(\mathrm{mg} \cdot \mathrm{kg}^{-1}\right)\end{array}$ & $\begin{array}{c}\mathrm{TKN} \\
(\%)\end{array}$ & $\begin{array}{c}\text { Phosphorus } \\
(\%)\end{array}$ & $\begin{array}{c}\text { Potassium } \\
(\%)\end{array}$ & $\begin{array}{c}\text { Calcium } \\
(\%)\end{array}$ & $\begin{array}{c}\text { Silicon } \\
(\%)\end{array}$ \\
\hline $\mathrm{N}_{0} \mathrm{P}_{0} \mathrm{~K}_{0}$ & 12.5 & 45 & 1.58 & 0.54 & 3.89 & 0.44 & 0.12 \\
$\mathrm{~N}_{0} \mathrm{P}_{0} \mathrm{~K}_{112}$ & 10.0 & 103 & 1.54 & 0.53 & 3.68 & 0.40 & 0.07 \\
$\mathrm{~N}_{0} \mathrm{P}_{112} \mathrm{~K}_{112}$ & 10.0 & 73 & 1.53 & 0.52 & 3.74 & 0.37 & 0.08 \\
$\mathrm{~N}_{0} \mathrm{P}_{225} \mathrm{~K}_{112}$ & 65.0 & 473 & 1.55 & 0.52 & 3.68 & 0.40 & 0.06 \\
$\mathrm{~N}_{112} \mathrm{P}_{112} \mathrm{~K}_{0}$ & 15.0 & 501 & 2.46 & 0.55 & 3.94 & 0.42 & 0.06 \\
$\mathrm{~N}_{112} \mathrm{P}_{0} \mathrm{~K}_{112}$ & 10.0 & 1390 & 1.97 & 0.54 & 3.35 & 0.40 & 0.06 \\
$\mathrm{~N}_{112} \mathrm{P}_{112} \mathrm{~K}_{112}$ & 180 & 1590 & 2.82 & 0.61 & 4.14 & 0.45 & 0.04 \\
$\mathrm{~N}_{112} \mathrm{P}_{225} \mathrm{~K}_{112}$ & 52.5 & 1020 & 2.41 & 0.58 & 3.79 & 0.39 & 0.05 \\
$\mathrm{~N}_{225} \mathrm{P}_{112} \mathrm{~K}_{0}$ & 97.5 & 2758 & 3.34 & 0.52 & 3.55 & 0.39 & 0.04 \\
$\mathrm{~N}_{225} \mathrm{P}_{0} \mathrm{~K}_{112}$ & 120 & 2686 & 3.44 & 0.62 & 3.19 & 0.44 & 0.04 \\
$\mathrm{~N}_{225} \mathrm{P}_{112} \mathrm{~K}_{112}$ & 85.0 & 1520 & 3.26 & 0.63 & 3.77 & 0.42 & 0.06 \\
$\mathrm{~N}_{225} \mathrm{P}_{225} \mathrm{~K}_{112}$ & 45.0 & 2788 & 3.25 & 0.58 & 3.28 & 0.40 & 0.06 \\
$\mathrm{~N}_{337} \mathrm{P}_{112} \mathrm{~K}_{0}$ & 70.0 & 2973 & 3.31 & 0.52 & 3.51 & 0.37 & 0.03 \\
$\mathrm{~N}_{337} \mathrm{P}_{0} \mathrm{~K}_{112}$ & 37.5 & 2683 & 3.28 & 0.56 & 2.99 & 0.39 & 0.04 \\
$\mathrm{~N}_{337} \mathrm{P}_{112} \mathrm{~K}_{112}$ & 95.0 & 2728 & 3.21 & 0.58 & 3.27 & 0.44 & 0.03 \\
$\mathrm{~N}_{337} \mathrm{P}_{225} \mathrm{~K}_{112}$ & 168.0 & 2103 & 3.43 & 0.58 & 3.42 & 0.44 & 0.04 \\
LSD $_{(0.05)}$ & 137.0 & 1217 & 0.57 & 0.07 & 0.57 & 0.06 & 0.02 \\
\hline
\end{tabular}

$\mathrm{TKN}=$ total Kjeldahl nitrogen; LSD = least significant difference.

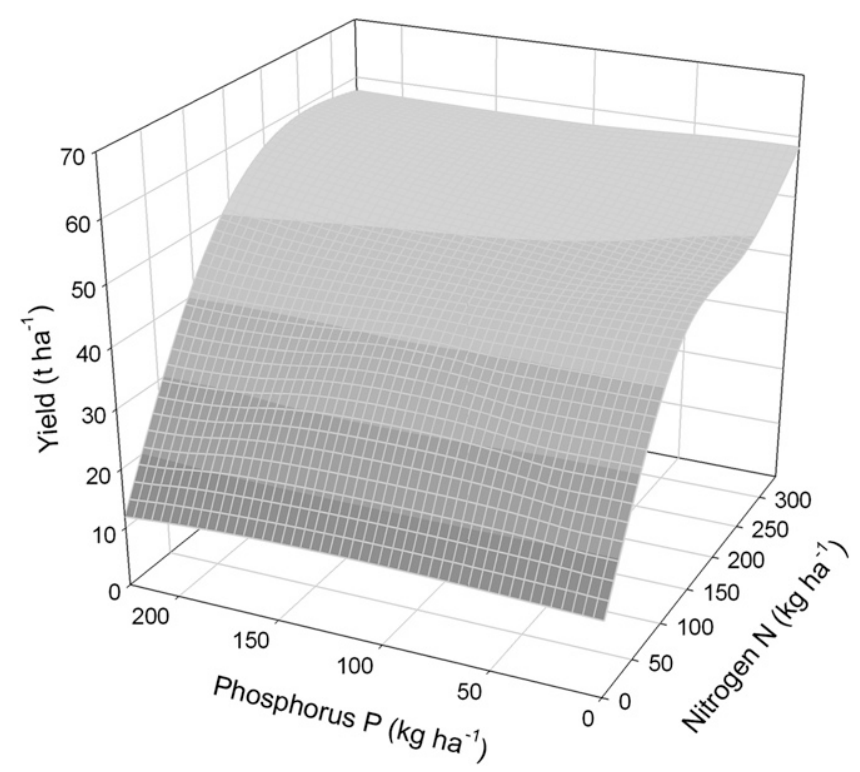

Fig. 1. Effect of application of various levels of nitrogen $(N)$, phosphorus $(P)$, and potassium $(\mathrm{K})$ fertilizers on the yield of romaine lettuce. Yield from the unfertilized control plots was $9.0 \mathrm{t} \cdot \mathrm{ha}^{-1}$. Yields from plots that did not receive $\mathrm{K}$ fertilizer were $39.3,47.6$, and $57.0 \mathrm{t} \cdot \mathrm{ha}^{-1}$ for $\mathrm{N}$ application rates of 112,225 , and $337 \mathrm{t} \cdot \mathrm{ha}^{-1}$, respectively. 


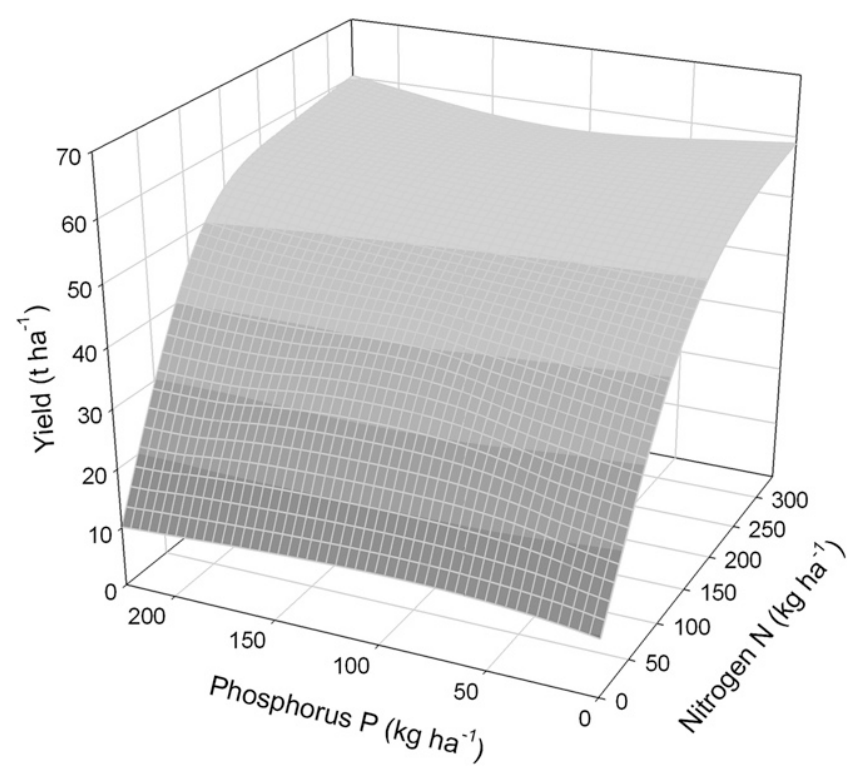

Fig. 2. Effect of application of various levels of nitrogen (N), phosphorus $(\mathrm{P})$, and potassium $(\mathrm{K})$ fertilizers on the yield of iceberg lettuce. Yield from the unfertilized control plots was $9.7 \mathrm{t} \cdot \mathrm{ha}^{-1}$. Yields from plots that did not receive $\mathrm{K}$ fertilizer were $40.8,51.3$, and $60.2 \mathrm{t} \cdot \mathrm{ha}^{-1}$ for $\mathrm{N}$ application rates of 112,225 , and $337 \mathrm{t} \cdot \mathrm{ha}^{-1}$, respectively.

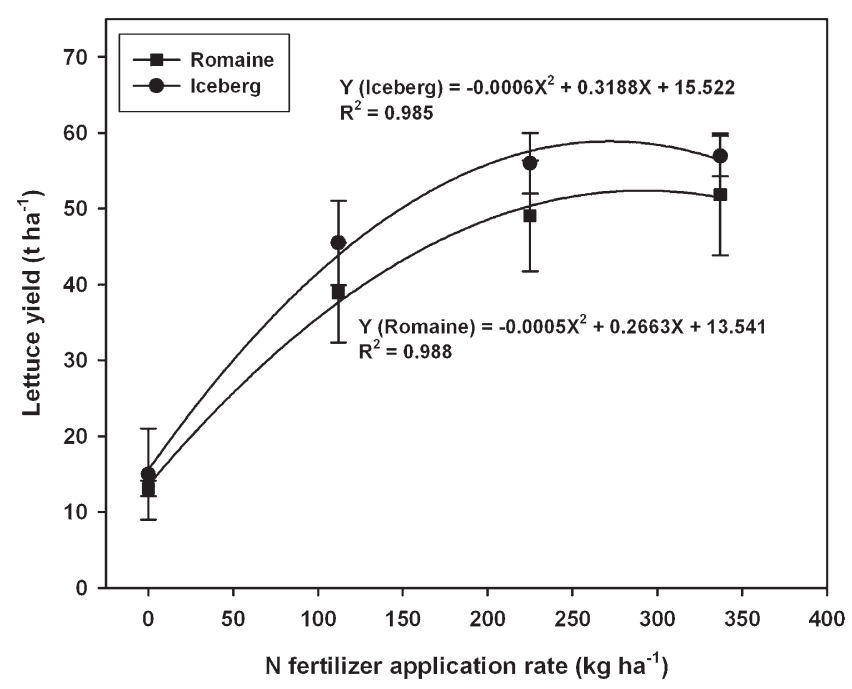

Fig. 3. Yield response to nitrogen $(\mathrm{N})$ fertilizer application for romaine and iceberg lettuce. Yields were averaged for the two growing seasons, 2002 and 2003.

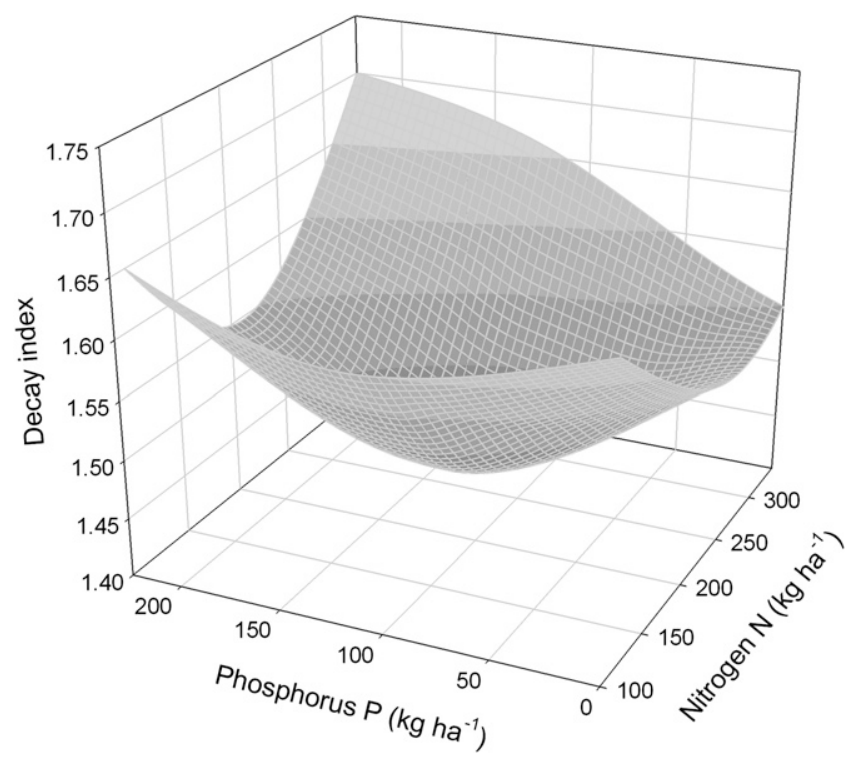

Fig. 4. Effect of application of various levels of nitrogen (N), phosphorus $(\mathrm{P})$, and potassium $(\mathrm{K})$ fertilizers on the decay index of stored romaine lettuce. The decay indices for plots that did not receive $\mathrm{K}$ fertilizer were $1.60,1.45$, and 1.65 for $\mathrm{N}$ application rates of 112,225 , and $337 \mathrm{t} \cdot \mathrm{ha}^{-1}$, respectively.

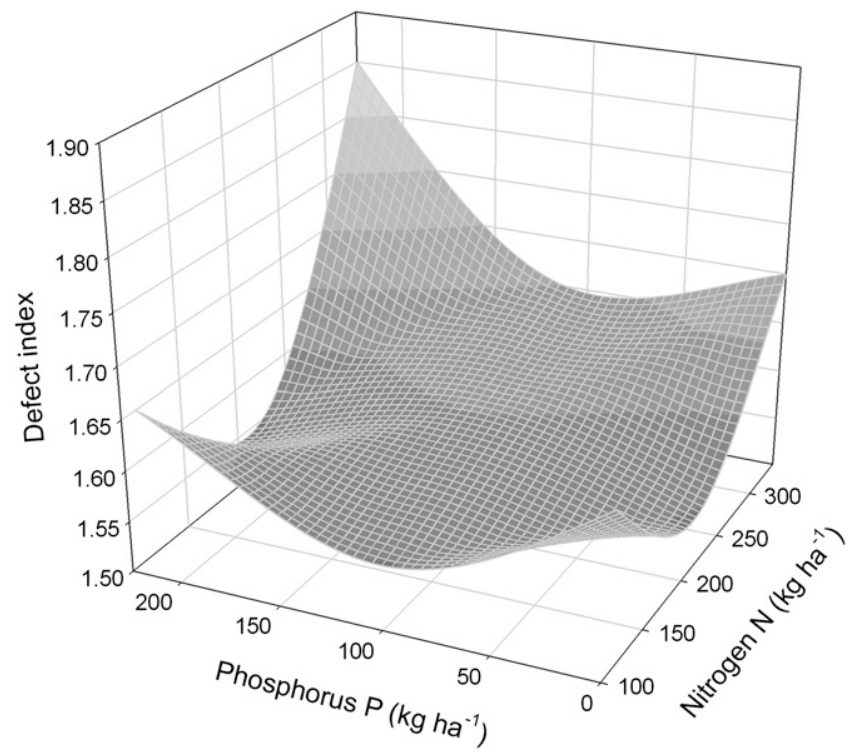

Fig. 5. Effect of application of various levels of nitrogen $(\mathrm{N})$, phosphorus $(\mathrm{P})$, and potassium $(\mathrm{K})$ fertilizers on the defect index of stored iceberg lettuce. The defect indices for plots that did not receive $\mathrm{K}$ fertilizer were $1.55,1.60$, and 1.65 for $\mathrm{N}$ application rates of 112,225 , and $337 \mathrm{t} \cdot \mathrm{ha}^{-1}$, respectively. possibly as a result of the high soil $\mathrm{K}$ content (Tables 1 and 2).

Lettuce postharvest quality. Lettuce is subject to many defects that can occur during growing, harvesting, handling, and transportation (Morris, 1974). Lettuce is also very sensitive to microbial attack, which reduces quality (Martinez-Romero et al., 2008).

Lettuce grown in soils without $\mathrm{N}$ fertilizer did not produce mature lettuce heads. Therefore, it was not possible to include these treatments in the postharvest evaluations. Application of $\mathrm{K}$ fertilizer did not affect the postharvest quality of stored lettuce (at $1^{\circ} \mathrm{C}$ ). Rates of $\mathrm{N}$ and $\mathrm{P}$ significantly influenced the postharvest quality of both types of lettuce. For romaine lettuce, postharvest quality was mainly affected by decay (Fig. 4). For iceberg lettuce, the postharvest quality was mostly affected by defects (Fig. 5). The least romaine decay and iceberg defects were found in the medium fertilizer rates of $\mathrm{N}$ and $\mathrm{P}(225$ $\mathrm{kg} \cdot \mathrm{ha}^{-1}$ of $\mathrm{N}$ plus $112 \mathrm{~kg} \cdot \mathrm{ha}^{-1}$ of $\mathrm{P}$ ) and the maximum decay and defects were found in the high rates of $\mathrm{N}$ and $\mathrm{P}\left(337 \mathrm{~kg} \cdot \mathrm{ha}^{-1}\right.$ of $\mathrm{N}$ plus $225 \mathrm{~kg} \cdot \mathrm{ha}^{-1}$ of $\mathrm{P}$ ).

Regardless of the fertilizer treatment, iceberg lettuce was more turgid and had less fringe burn than romaine lettuce after $21 \mathrm{~d}$ of cold storage. Change in wilt and decay for romaine lettuce are shown in Table 5 and changes in defect and fringe burn for iceberg are shown in Table 6. Except for the highest $\mathrm{N}$ and $\mathrm{P}$ application rate, changes in postharvest quality were similar for all treatments after 2 weeks of cold storage. However, quality declined rapidly with increased storage time from 2 to 3 weeks. Heimdal et al. (1995) stated that lettuce should be stored no longer than $10 \mathrm{~d}$ to avoid the loss of color and nutritional value. In our study, loss of green color was mainly observed in romaine lettuce after 3 weeks of cold storage.

The combined index for all postharvest quality indices of romaine and iceberg lettuce 
after 3 weeks of cold storage are shown in Figures 6 and 7, respectively. The combined quality index varied widely among the different $\mathrm{N}$ and $\mathrm{P}$ fertilization rates, but the highest $\mathrm{P}$ and $\mathrm{N}$ fertilizer application rate resulted in

the worst postharvest quality of stored lettuce. Also, a high application rate of $\mathrm{N}\left(337 \mathrm{~kg} \cdot \mathrm{ha}^{-1}\right)$ without sufficient $\mathrm{P}$ (less than $112 \mathrm{~kg} \cdot \mathrm{ha}^{-1}$ ) had a negative effect on the overall postharvest quality of romaine lettuce. Ryder (1999) spec-

Table 5. Time change differences in postharvest quality parameters for romaine lettuce.

\begin{tabular}{lcccr}
\hline & \multicolumn{2}{c}{ Change in wilt index } & \multicolumn{2}{c}{ Change in decay index } \\
\cline { 2 - 3 } Treatment & Week 2 & Week 3 & Week 2 & Week 3 \\
\hline $\mathrm{N}_{112} \mathrm{P}_{112} \mathrm{~K}_{0}$ & 0.20 & 0.45 & 0.15 & 0.45 \\
$\mathrm{~N}_{112} \mathrm{P}_{0} \mathrm{~K}_{112}$ & 0.15 & 0.50 & 0.15 & 0.50 \\
$\mathrm{~N}_{112} \mathrm{P}_{112} \mathrm{~K}_{112}$ & 0.20 & 0.45 & 0.20 & 0.55 \\
$\mathrm{~N}_{112} \mathrm{P}_{225} \mathrm{~K}_{112}$ & 0.25 & 0.55 & 0.15 & 0.50 \\
$\mathrm{~N}_{225} \mathrm{P}_{112} \mathrm{~K}_{0}$ & 0.25 & 0.50 & 0.20 & 0.45 \\
$\mathrm{~N}_{225} \mathrm{P}_{0} \mathrm{~K}_{112}$ & 0.20 & 0.50 & 0.15 & 0.45 \\
$\mathrm{~N}_{225} \mathrm{P}_{112} \mathrm{~K}_{112}$ & 0.20 & 0.45 & 0.20 & 0.40 \\
$\mathrm{~N}_{225} \mathrm{P}_{225} \mathrm{~K}_{112}$ & 0.20 & 0.45 & 0.25 & 0.50 \\
$\mathrm{~N}_{337} \mathrm{P}_{112} \mathrm{~K}_{0}$ & 0.20 & 0.45 & 0.25 & 0.55 \\
$\mathrm{~N}_{337} \mathrm{P}_{0} \mathrm{~K}_{112}$ & 0.25 & 0.45 & 0.25 & 0.50 \\
$\mathrm{~N}_{337} \mathrm{P}_{112} \mathrm{~K}_{112}$ & 0.15 & 0.50 & 0.15 & 0.55 \\
$\mathrm{~N}_{337} \mathrm{P}_{225} \mathrm{~K}_{112}$ & 0.30 & 0.65 & 0.35 & 0.70 \\
$\mathrm{LSD}_{(0.05)}$ & 0.05 & 0.05 & 0.05 & 0.05 \\
\hline
\end{tabular}

$\mathrm{LSD}=$ least significant difference.

Table 6. Time change differences in postharvest quality parameters for iceberg lettuce.

\begin{tabular}{lcccc}
\hline & \multicolumn{2}{c}{ Change in defect index } & & \multicolumn{2}{c}{ Change in fringe burn index } \\
\cline { 2 - 3 } Treatment & Week 2 & Week 3 & & Week 2 \\
\hline $\mathrm{N}_{112} \mathrm{P}_{112} \mathrm{~K}_{0}$ & 0.20 & 0.45 & 0.20 & 0.55 \\
$\mathrm{~N}_{112} \mathrm{P}_{0} \mathrm{~K}_{112}$ & 0.25 & 0.45 & 0.30 & 0.50 \\
$\mathrm{~N}_{112} \mathrm{P}_{112} \mathrm{~K}_{112}$ & 0.20 & 0.40 & 0.15 & 0.50 \\
$\mathrm{~N}_{112} \mathrm{P}_{225} \mathrm{~K}_{112}$ & 0.10 & 0.45 & 0.25 & 0.55 \\
$\mathrm{~N}_{225} \mathrm{P}_{112} \mathrm{~K}_{0}$ & 0.10 & 0.40 & 0.20 & 0.45 \\
$\mathrm{~N}_{225} \mathrm{P}_{0} \mathrm{~K}_{112}$ & 0.25 & 0.50 & 0.25 & 0.45 \\
$\mathrm{~N}_{225} \mathrm{P}_{112} \mathrm{~K}_{112}$ & 0.25 & 0.50 & 0.25 & 0.60 \\
$\mathrm{~N}_{225} \mathrm{P}_{225} \mathrm{~K}_{112}$ & 0.25 & 0.50 & 0.30 & 0.40 \\
$\mathrm{~N}_{337} \mathrm{P}_{112} \mathrm{~K}_{0}$ & 0.15 & 0.30 & 0.50 & 0.40 \\
$\mathrm{~N}_{337} \mathrm{P}_{0} \mathrm{~K}_{112}$ & 0.20 & 0.45 & 0.25 & 0.50 \\
$\mathrm{~N}_{337} \mathrm{P}_{112} \mathrm{~K}_{112}$ & 0.20 & 0.45 & 0.25 & 0.50 \\
$\mathrm{~N}_{337} \mathrm{P}_{225} \mathrm{~K}_{112}$ & 0.35 & 0.85 & 0.30 & 0.75 \\
LSD $_{(0.05)}$ & 0.05 & 0.05 & 0.05 & 0.05 \\
\hline
\end{tabular}

LSD $=$ least significant difference.

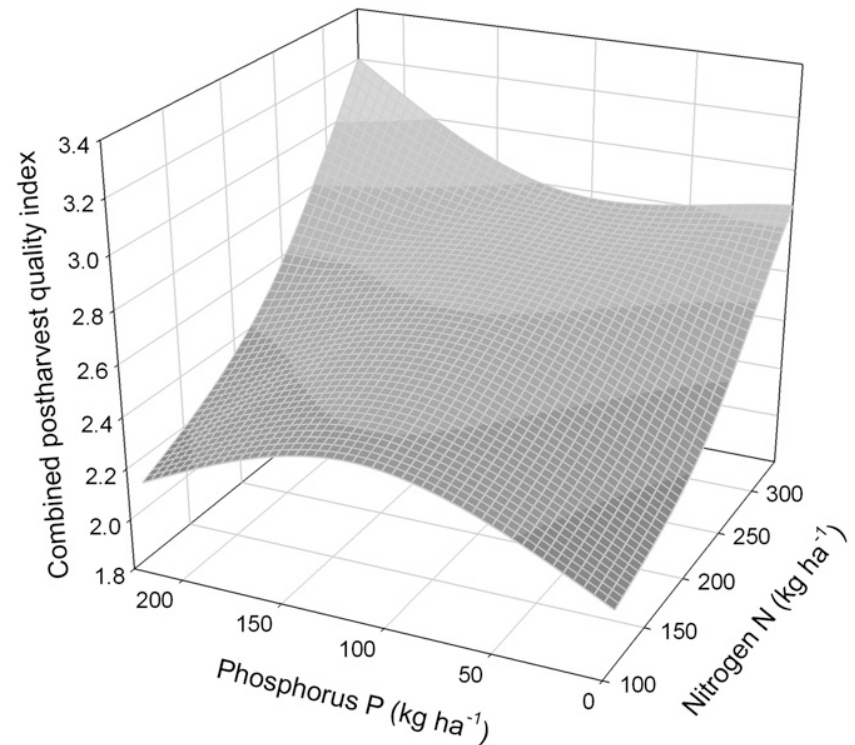

Fig. 6. Effect of application of various levels of nitrogen (N), phosphorus $(\mathrm{P})$, and potassium $(\mathrm{K})$ fertilizers on the combined postharvest quality index of stored romaine lettuce. The combined indices for plots that did not receive $\mathrm{K}$ fertilizer were $2.0,2.2$, and 2.9 for $\mathrm{N}$ application rates of 112,225 , and $337 \mathrm{t} \cdot \mathrm{ha}^{-1}$, respectively. ulated that moderate reduction of applied $\mathrm{P}$ mitigates the effects of high nitrate, whereas adequate growth is maintained. However, high rates of $\mathrm{N}$ supply may increase the severity of infections by obligate parasites, which in turn affect the yield and quality.

Other studies found that high rates of $\mathrm{N}$ can reduce the soluble sugar and increase the acid to sugar ratio and may lower the sugar content of lettuce, which can accelerate the deterioration of postharvest quality of stored lettuce as a result of lower respiration (Wang et al., 2008; Yuji et al., 1980). However, Yuji et al. (1980) speculated that higher sugar content could help bring about better respiration and a lower degradation rate of chlorophyll during storage. In our study, the high rate of $\mathrm{P}$ combined with high $\mathrm{N}$ produced the worst overall postharvest quality (the highest combined index) for both lettuce types. High $\mathrm{P}$ concentrations can inhibit starch synthesis mainly by decreasing the incorporation of the fixed carbon into starch in the leaf (Marschner, 1995) and simple sugar can accumulate in cells. Glucose content in fresh lettuce tissues (Figs. 8 and 9) resembles the combined postharvest quality index (Figs. 6 and 7), supporting the fact that high $\mathrm{P}$ and $\mathrm{N}$ application rates will increase the sugar content, which, in turn, can increase the severity of bacterial infestation. The strong correlation $\left(R^{2}=0.84\right)$ between lettuce leaf glucose content and the postharvest quality index suggests that glucose can be an excellent indicator of the shelf life of cold-stored lettuce.

\section{Conclusions}

Application of moderate rates of $\mathrm{N}$ and $\mathrm{P}$ increased romaine and iceberg lettuce yield and enhanced postharvest quality. Application of $\mathrm{N}, \mathrm{P}$, and $\mathrm{K}$ is recommended in soils

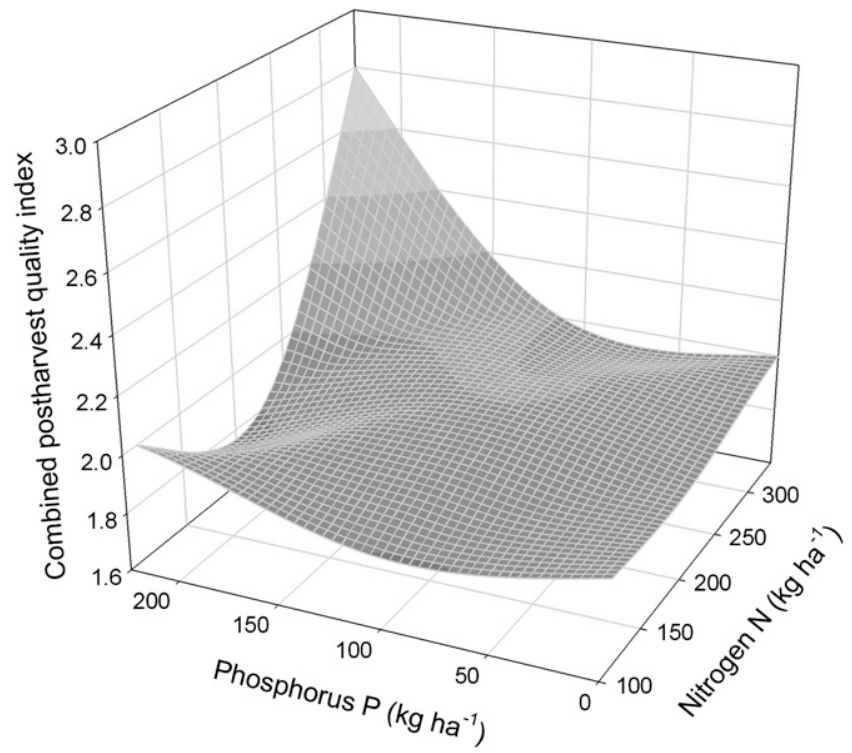

Fig. 7. Effect of application of various levels of nitrogen $(\mathrm{N})$, phosphorus $(\mathrm{P})$, and potassium $(\mathrm{K})$ fertilizers on the combined postharvest quality index of stored iceberg lettuce. The combined indices for plots that did not receive $\mathrm{K}$ fertilizer were $1.8,2.1$, and 2.2 for $\mathrm{N}$ application rates of 112,225 , and $337 \mathrm{t} \cdot \mathrm{ha}^{-1}$, respectively. 


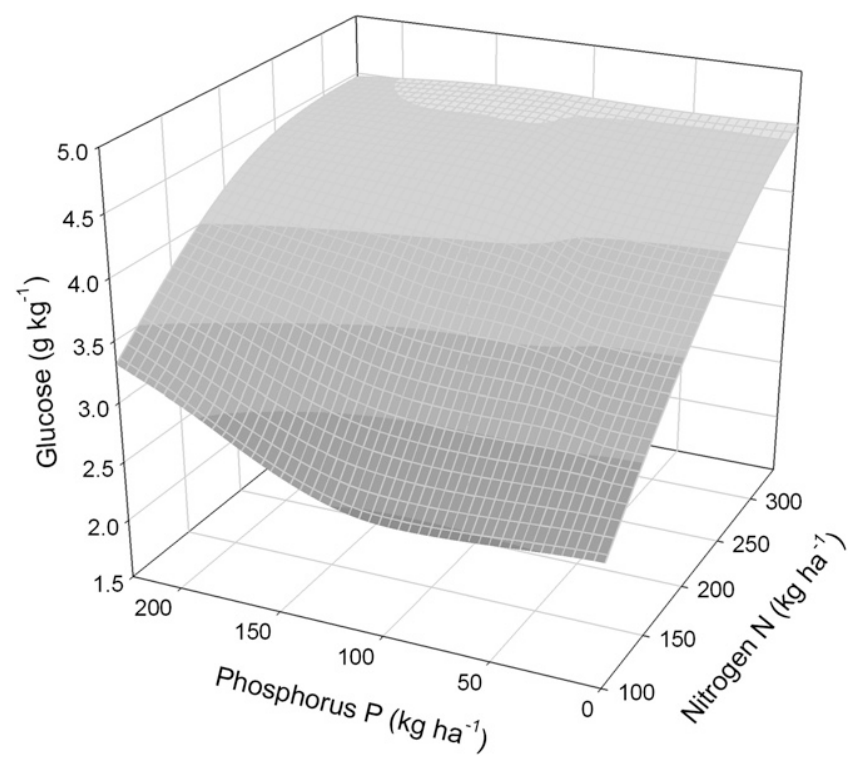

Fig. 8. Effect of application of various levels of nitrogen $(\mathrm{N})$, phosphorus $(\mathrm{P})$, and potassium $(\mathrm{K})$ fertilizers on leaf glucose content of fresh romaine lettuce. The leaf glucose content in plots that did not receive $\mathrm{K}$ fertilizer was $2.6,3.9$, and $4.6 \mathrm{~g} \cdot \mathrm{kg}^{-1}$ for $\mathrm{N}$ application rates of 112 , 225 , and $337 \mathrm{t} \cdot \mathrm{ha}^{-1}$, respectively.

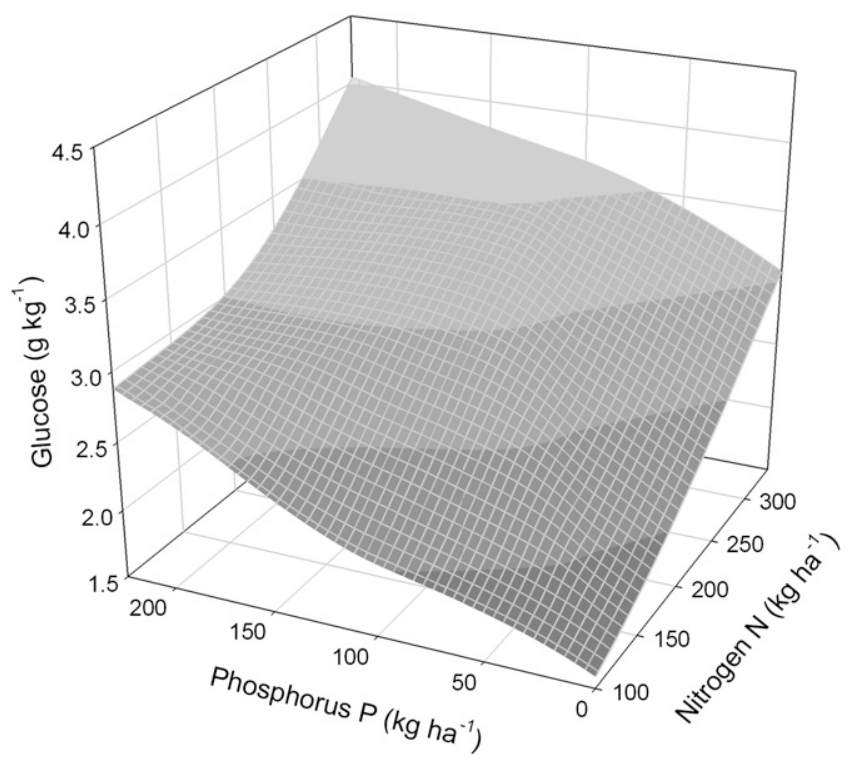

Fig. 9. Effect of application of various levels of nitrogen (N), phosphorus $(\mathrm{P})$, and potassium $(\mathrm{K})$ fertilizers on leaf glucose content of fresh iceberg lettuce. The leaf glucose content in plots that did not receive $\mathrm{K}$ fertilizer was $1.8,3.0$, and $3.8 \mathrm{~g} \cdot \mathrm{kg}^{-1}$ for $\mathrm{N}$ application rates of 112 , 225 , and $337 \mathrm{t} \cdot \mathrm{ha}^{-1}$, respectively. that are deficient in theses nutrients. There were positive effects of applying moderate rates of $\mathrm{N}$ and $\mathrm{P}$ fertilization and there were negative effects of applying high rates of $\mathrm{N}$ and $\mathrm{P}$ on postharvest quality parameters for both iceberg and romaine lettuce. Weight and visual quality parameters during the storage time in this study increased as a result of the application of $\mathrm{N}$ and $\mathrm{P}$. However, based on our study, a proper balance of $\mathrm{N}$ and $\mathrm{P}$ fertilizers improved the marketable yield and postharvest quality of cold storage lettuce.

\section{Literature Cited}

Alt, D. 1987. Influence of $P$ and $K$ fertilization on the yield of different vegetable species. J. Plant Nutr. 10:1429-1435.

Bidwell, R.G.S. 1974. Plant physiology. Macmillan Publishing Co., New York, NY

Buysse, J. and R. Merckx. 1993. An improved colorimetric method to quantify sugar content of plant tissue. J. Expt. Bot. 44:1627-1629.

Carling, D.E., G.J. Michaelson, C.L. Ping, and G.A. Mitchell. 1987. The effect of nitrogen fertilization rates on head lettuce yields: A preliminary report. Agricultural and Forestry Experiment Station, School of Agriculture and Land Resources Management, University of Alaska-Fairbanks. Report no. 3, p. 1-4

Cleaver, T.S. and D.J. Greenwood. 1975. Ready Reckoner to predict best fertilizer for vegetables. Grower 83:1269-1271.

David, S., T.L. Righetti, E.E. Sanchez, and H. Khemira. 1992. Management of nitrogen and calcium in pear trees for enhancement of fruit resistance to postharvest quality. HortTechnology 2:382-386.

Fageria, N.K. 2009. The use of nutrients in crop plants. Taylor and Francis Group, Boca Raton, FL.

Fontes, P.C.R., P.R.G. Pereira, and R.M. Conde. 1997. Critical chlorophyll, total nitrogen and nitrate nitrogen in leaves associated to maximum lettuce yield. J. Plant Nutr. 20:1061-1068.
Heckman, J.R. 2007. Sweet corn nutrition uptake and removal. HortTechnology 17:82-86.

Heckman, J.R., J.T. Sims, D.E. Beegle, F.J. Coale, S.J. Herbert, T.W. Bruulsema, and W.J. Bamka. 2003. Nutrient removal by corn grain harvest. Agron. J. 95:587-591.

Heimdal, H.B., F. Kuhn, L. Poll, and L.M. Larsen. 1995. Biochemical changes and sensory quality of shredded and MA packaged iceberg lettuce. J. Food Sci. 60:1265-1268.

Jackson, L.E., L.J. Stivers, B.T. Warden, and K.K. Tanji. 1994. Crop nitrogen utilization and soil nitrate loss in a lettuce field. Fert. Res. 37:93105.

Johnstone, P.R., T.K. Hartz, M.D. Cahn, and M.R Johnstone. 2005. Lettuce response to phosphorus fertilization in high phosphorus soils. HortScience 40:1499-1503.

Kader, A.A., W.J. Lipton, and L.L. Morris. 1973. System for scoring quality of harvested lettuce. HortScience 5:408-409.

Manotti, P.L., D.E. Halseth, and J.B. Sieczka 1994. Field chlorophyll measurements to assess the $\mathrm{N}$ status of potato varieties. HortScience 29:1497-1500.

Marschner, H. 1995. Mineral nutrition of higher plants. 2nd Ed. Academic Press Inc., San Diego, CA.

Martinez-Romero, D., M. Serrano, G. Bailén, F. Gullén, P.J. Zapata, J.M. Valverde, S. Castillo, M. Fuentes, and D. Valero. 2008. The use of a natural fungicide as an alternative to preharvest synthetic fungicide treatments to control lettuce deterioration during postharvest storage. Postharvest Biol. Technol. 47:54-60.

Morris, L.L. 1974. Postharvest handling of lettuce ASHRAE Trans. 80:341-349.

Morris, L.L., J.A. Klautermeyer, and A.A. Kader. 1974. Postharvest requirements of lettuce to control physiological disorders, p. 22-29. Proc. 26th Int'l Conf. Handl. Perish. Agr. Comm. 10-12 Sept. Michigan State University, East Lansing, MI

Nagda, C.L. and K.S. Chauhan. 1991. Responses of cauliflower to nitrogen and sulphur application. Indian J. Hort. 15:62-67.
Ryder, E.J. 1999. Lettuce, endive and chicory, p. 79-89. Crop Production Sci in Hort. 9. CABI Publishing, Wallingford, UK.

Sanchez, C.A. and H.W. Burdine. 1988. Response of lettuce to soil test P and K levels. Soil and Crop Sci. Soc. Fla. Pro. 47:52-55.

Sanchez, C.A., H.W. Burdine, V.L. Guzman, and C.B. Hall. 1988. Yield, quality, and leaf nutrient composition of crisphead lettuce as affected by N, P, and K on histosols. Proc. Fla. State Hort. Soc. 101:346-350.

SAS Institute. 1996. The SAS system for Windows. Release 6.12. SAS Inst., Cary, NC.

Sims, J.T. 1998. Phosphorus soil testing: Innovations for water quality protection. Commun. Soil Sci. Plant Anal. 29:1471-1489.

Sims, J.T., R.R. Simard, and B.C. Joern. 1998 Phosphorus loss in agricultural drainage: Historical perspective and current research. J. Environ. Qual. 27:277-293.

Smith, R., T. Bensen, H. Ajwa, and S. Klose. 2006 Phosphorus fertilizer evaluation on head lettuce in the Salinas Valley. Crop Notes, University of California. Cooperative Extension, Monterey County Newsletter. Mar/Apr:4-5.

Soundy, P. and I.E. Smith. 1992. Response of lettuce (Lactuca sativa L.) to nitrogen and phosphorus fertilization. J. S. Afr. Soc. HortScience 2:82-85

Tittonell, P., J.D. Grazia, and A. Chiesa. 2001 Effect of nitrogen fertilization and plant population during growth on lettuce (Lactuca sativa L.) postharvest quality. Acta Hort. 553: 67-68

Wang, Z.H., S. Li, and S. Malhi. 2008. Effects of fertilization and other agronomic measures on nutritional quality of crops. J. Sci. Food Agr. $88: 7-23$.

Yuji, K., N. Satoshi, and K. Takeshi. 1980. Quality of horticultural crops and soil environmental conditions. III. Influence of soil environmental conditions on quality and the storage life of lettuce cv. 'Great Lakes 366'. Shizuka-Ken Nogyo Shikenjo Kenkyo Houkoku (Bulletin of the Shizouka prefectural Agr. Expt. Sta.). p. $36-45$.

HortScience Vol. 45(10) October 2010 